Original Research Paper

\title{
The Influence of Garcinia kola Seed on Sexual Behavior and Testis Physiology in Wistar Rats
}

\author{
Jonah Sydney Aprioku, Victor Nwachukwu, Blessing Ukamaka Okeke, \\ Obinna Okubuike, Reginald Obi Igbo and Joy Okareko Emakpor \\ Department of Experimental Pharmacology and Toxicology, Faculty of Pharmaceutical Sciences, \\ University of Port Harcourt, East-West Road, Choba, Rivers State, PMB 5323, Nigeria
}

Article history

Received: 02-12-2017

Revised: 24-02-2018

Accepted: 24-04-2018

Corresponding Author: Jonah Sydney Aprioku Department of Experimental Pharmacology and Toxicology, Faculty of Pharmaceutical Sciences, University of Port Harcourt, East-West Road, Choba, Rivers State, PMB 5323, Nigeria

Tell $+234(0) 8035082379$

Email: sydaprio@yahoo.com

\begin{abstract}
Garcina kola seed is believed by some to enhance male sexual performance but existing scientific data show divergent results. In this study, the sexual and reproductive influence of ethanol (70\%) seed extract of G. kola was evaluated in Wistar rats. Adult male rats were gavaged with $0,50,100,200$ or $300 \mathrm{mg} \mathrm{kg}^{-1}$ day $^{-1}$ of extract for 30 days and mated with female rats after sexual behavior characteristics were carefully evaluated. Serum concentrations of testosterone, $\mathrm{LH}$ and FSH, as well as epididymal sperm indices were analyzed after mating, while pregnancy rate and litter size of female rats were recorded. Extract $\left(50 \mathrm{mg} \mathrm{kg}^{-1}\right)$ treatment produced no effect on sexual activities, but higher doses caused reduction relative to control. Additionally, except at $50 \mathrm{mg} \mathrm{kg}{ }^{-1}$, extract treatment caused reduction in sperm count $(p<0.0001)$, sperm viability $(p=0.0011)$, testosterone and FSH $(p<0.0001)$. LH was unaltered, while abnormal sperm morphology was elevated $(\mathrm{p}<0.05)$. Furthermore, pregnancy rate and litter size in extract (100-300 mg kg$\left.{ }^{-1}\right)$ treated rats were lower when compared to control. The results suggest that low dose of G. kola seed may not affect sexual activity, whereas high doses may affect fertility by negatively altering sexual behavior, testosterone level and sperm indices.
\end{abstract}

Keywords: Bitter Kola, Garcinia kola, Infertility, Sperm Parameters, Gonadal Function

\section{Introduction}

Medicinal plants are increasingly relied upon for maintenance of personal health and wellbeing. It has been estimated by the World Health Organization (WHO) that a large global population rely on herbal medicines for some aspect of their health care needs, partly because they are cheap and easily accessible compared to orthodox medicines and also because of the belief that they are effective in the treatment of a wide range of ailments (Barata et al., 2016). Garcina kola (Family, Gultiferae) is one of the most widely consumed medicinal plants in Africa. It is popularly known as "Bitter Kola" in Nigeria because of the bitter taste of the seed, but is also identified by other local names in different regions of the country. The plant has been referred to as a "Wonder Plant" because every part of it is found to be of medicinal importance (Okoye et al., 2014). The numerous ethno-medicinal uses of the plant include, treatment of abdominal discomfort, headache, cough, throat infections, vomiting and impotence (Adesina et al., 1995; Ofor et al., 2004; Okoye et al., 2014). It has equally been used locally for the treatment liver diseases, diarrhea, microbial infections and as a general antidote (Ibiblio, 1983; Iwu, 1989; Ofor et al., 2004; Adegboye et al., 2008). Most of the folkloric uses of $G$. kola have been authenticated, but its beneficial role in the treatment of male infertility is yet to be substantiated with scientific proof.

Infertility is a global problem, with a global prevalence rate of 10.5\% (Mascarenhas et al., 2012) and second most prevalent health care problem in sub-Sahara Africa (Chinnoch, 1996). In Nigeria, prevalence of infertility was alarmingly reported to be $40-50 \%$ (Emokpae et al., 2005; Okonofua et al., 2005). G. kola seed is consumed by some to increase sexual desire or performance (Iwu, 1989; Ngueyem et al., 2009) but unfortunately, existing data show conflicting reports on 
this in experimental animal studies (Ralebona et al., 2012; Yakubu and Quadri AL, 2012; Sewani-Rusike et al., 2016). Additionally, some studies have indicated that $G$. kola negatively affects spermatogenic indices (Chilaka et al., 2009; Abua et al., 2013; Mesembe et al., 2013), while others concluded that it enhances male reproductive indices (Adesanya et al., 2007; Atsukwei et al., 2015; Sewani-Rusike et al., 2016). More so, despite the wide consumption of $G$. kola, infertility rate is relatively high in regions where it is highly distributed with the implication that the plant may contribute to infertility.

The present study aims to evaluate the influence of $G$ kola on male reproductive function by investigating the effect of 30 days oral treatment with ethanol extract of $G$ kola seed on sexual behavior, sperm parameters, serum reproductive hormone concentrations and fertility potential in Wistar rats.

\section{Materials and Methods}

\section{Animals}

Thirty male (200-250 g body weight) and thirty female Wistar rats (200-220 g body weight) were obtained from the Department of Experimental Pharmacology and Toxicology, Faculty of Pharmaceutical Sciences, University of Port Harcourt, Nigeria. All animals were acclimated for a period of 14 days before commencement of the study. They were fed with rat pellets and allowed access to tap water ad libitum. They were housed and maintained under standard laboratory conditions at ambient temperature $\left(26 \pm 5^{\circ} \mathrm{C}\right)$ and humidity with a $12 \mathrm{~h}$ photoperiod. The animals were handled humanly in compliance with the guidelines for care and use of laboratory animals in biomedical research (CCAC, 2009). All experimental procedures were approved by the Research Ethics Committee of the University of Port Harcourt, Nigeria.

\section{Methods}

\section{Extraction of Plant Material}

Fresh Garcinia kola seed was purchased from a local fruit market in Port Harcourt, Rivers State, Nigeria. The plant was identified and authenticated by a botanist, Mr. M. Suleiman of the Department of Pharmacognosy and Phytotherapy, Faculty of Pharmaceutical Sciences, University of Port Harcourt, Nigeria and assigned a voucher number, DPH048 which was deposited at the herbarium of the Faculty. Following identification, the seeds were allowed to air dry for one week and later dried in an oven at $40^{\circ} \mathrm{C}$ until a constant weight was obtained. The dried seeds were then ground to powder and macerated in $70 \%$ ethanol $(1: 5)$ for $72 \mathrm{~h}$ with regular agitation. The mixture was filtered using Whatman number 51 filter paper and the resulting filtrate was evaporated using a rotary evaporator to obtain a pasty extract. This was evaporated further in a steam bath $\left(40^{\circ} \mathrm{C}\right)$ to obtain a brownish-black dry extract and stored in a refrigerator until used for experiments. The percentage yield was calculated, 19.4\% w/w (1000 g powder yielded $194 \mathrm{~g}$ extract).

\section{Phytochemical Screening of G. kola Seed Extract}

Phytochemical screening was conducted on the extract to determine the presence of various chemical constituents like alkaloids, saponins, tannins, flavonoids, steroids, anthraquinones, cardiac glycosides and carbohydrate using standard procedures (Sofowora, 1993; Trease and Evans, 2009).

\section{Experimental Design}

Sixty rats (thirty males and thirty females) were used in the study. The male rats were randomized into five groups ( $\mathrm{n}=6$ rats per group) and administered vehicle (DMSO plus water, 1:2); or extract $(50,100,200$ or 300 $\left.\mathrm{mg} \mathrm{kg}^{-1}\right)$ once daily by oral gavage $\left(2 \mathrm{ml} \mathrm{kg}^{-1}\right)$ for 30 days. The doses chosen were based on previous works (Braide et al., 2003; Sewani-Rusike et al., 2016) and well below the oral $\mathrm{LD}_{50}$ value of the extract $(5000 \mathrm{mg}$ $\mathrm{kg}^{-1}$ ) reported (Atsukwei et al., 2015). At the end of extract treatment, they were paired $(1: 1)$ and sexual behavior characteristics in all groups were closely monitored and recorded as described by Yakubu et al. (2012). After sexual behavior testing, animals were allowed further to mate freely with female rats for an hour twice daily. Mating was confirmed by the observation of vaginal plug in female rats. Thereafter, male rats were sacrificed by cervical dislocation under deep diethyl ether anesthesia. Blood was collected via cardiac puncture with sterile syringes and needles, serum was separated and testosterone, LH and FSH levels were assayed by Enzyme Linked Immunoassay (ELISA) method using commercially available kits. Testis was removed and epididymal sperm was analyzed. Also, the female rats were closely monitored after mating. Pregnant rats, confirmed by the presence of vaginal plug, were separated and monitored until littering. The number of pregnancies and number of pups delivered by animals in each group were recorded.

\section{Sexual Behavior Test}

Female rats were given single dose of estradiol benzoate $(25 \mu \mathrm{g} / \mathrm{kg}$, sc in $0.1 \mathrm{~mL}$ sesame oil) $48 \mathrm{~h}$ prior to pairing and progesterone $(500 \mu \mathrm{g}$, sc in $0.1 \mathrm{~mL}$ propylene glycol) $5 \mathrm{~h}$ before commencement of the evaluation to bring the animals to estrus phase in order to make them receptive (Kutzler, 2007; Lopez et al., 2007). Sexual behavior characteristics monitoring was conducted in a dark room $2 \mathrm{~h}$ after the last dose of extract treatment. To familiarize the animals to the behavior testing environment, animals were brought to the laboratory and exposed to dim light around $8 \mathrm{pm}$ 
daily for 6 days before the monitoring. Female rats were introduced into cages containing male rats one at a time and observation for sexual behavior was started immediately after the introduction of female rats and recorded as they occurred over $20 \mathrm{~min}$. The sexual behavior parameters measured include: precoital behavior characteristics (qualitative observation of chasing, nosing, sniffing and genital grooming); mount frequency (MF, number of mounts without intromission); intromission frequency (IF, number of intromission or penetration); and ejaculation frequency (EF, number of ejaculations). The qualitative observations of chasing, nosing, sniffing and genital grooming were scored as absent, mild, moderate or high depending on the frequency of occurrence of the events.

\section{Sperm Analysis}

Sperm was expressed from the epididymis into a clean glass slide and emulsified with equal volume of $1 \% \mathrm{NaHCO}_{3}$ buffered Tyrodes Lactate solution on a clean dry glass slide. The slide was viewed under a light microscope to analyze sperm motility, count, viability and morphology using standard methods (Ochei and Kolhatker, 2002; Baker, 2007). Briefly, sperm motility was determined by counting both motile and non-motile spermatozoa in 10 randomly selected fields using $40 \mathrm{x}$ magnification. The percentage of motile sperm was calculated from the mean percentage motility for all the fields counted. Sperm count was determined using the new improved Neubauer counting chamber. The chamber was prepared and charged with diluted seminal fluid $(1: 20)$ and allowed to stand in a moist chamber for $15 \mathrm{~min}$. This was then viewed under the microscope and complete morphologically mature sperm cells were counted using 40x magnification. For sperm morphology, sperm smears were stained on microscopic slides with two drops of Walls and Ewas after air-drying. The slides were examined under brightfield optics at 100x magnification with oil immersion. Two hundred spermatozoa were counted and the percentage of abnormal forms (morphology) was calculated.

\section{Statistical Analysis} analyzed by one way ANOVA followed by Dunnett's
All the values (data) obtained from the study were

posttest using GraphPad Prism Version 5 software (GraphPad Software Inc., San Diego, CA, USA). Student's $t$-test was also carried out where applicable. The values are expressed as Mean \pm Standard Deviation of Mean and $p$ values $<0.05$ were considered significant.

\section{Results}

\section{Phytochemical Analysis}

Garcina kola seed extract contained flavonoids, alkaloids, tannins, steroids, saponins and carbohydrates, but did not show presence of cardiac glycosides and anthraquinones (Table 1).

\section{Effect of Extract on Sexual Behavior}

Precoital behavior characteristics (chasing, nosing, sniffing and genital grooming) were observed and recorded qualitatively. Sniffing and nosing occurred highly, whereas chasing and genital grooming were observed to be moderate among control rats (Table 2). All four precoital behavior indices were highly exhibited by rats that received the lowest dose $\left(50 \mathrm{mg} \mathrm{kg}^{-1}\right)$ of extract. Conversely, precoital activities were absent in rats that were administered the highest dose $\left(300 \mathrm{mg} \mathrm{kg}^{-1}\right)$, except chasing and genital grooming that occurred mildly. In addition, sniffing, chasing and genital grooming occurred moderately, while nosing was mild in $100 \mathrm{mg} \mathrm{kg}^{-1}$ extract treated rats. Further, chasing was moderate, sniffing and genital grooming were mild, but there was no nosing observed in $200 \mathrm{mg} \mathrm{kg}^{-1}$ extract treated rats (Table 2).

Table 1: Phytochemical constituents of ethanol seed extract of Garcina kola

\begin{tabular}{ll}
\hline Phytochemical constituent & Observation \\
\hline Alkaloids & ++ \\
Saponins & ++ \\
Tannins & ++ \\
Flavonoids & +++ \\
Steroids & + \\
Anthraquinones & - \\
Cardiac glycosides & - \\
Terpenoids & ++ \\
Carbohydrates & ++ \\
\hline - Absent; + Mildly present; ++ Moderately & present; +++ \\
Abundantly present &
\end{tabular}

Table 2: Effect of 30 days treatment with ethanol seed extract of Garcina kola on precoital behavior in male Wistar rats

\begin{tabular}{lllll}
\hline & Precoital behavior parameters & & \\
Dose $(\mathrm{mg} / \mathrm{kg})$ & - & Nosing & Chasing & Genital Grooming \\
\hline Control & Sniffing & +++ & ++ & ++ \\
50 & ++ & +++ & +++ & ++ \\
100 & ++ & + & ++ & + \\
200 & ++ & - & ++ & + \\
300 & + & - & + & + \\
\hline
\end{tabular}

- Absent; + Mild; ++ Moderate; +++ High 


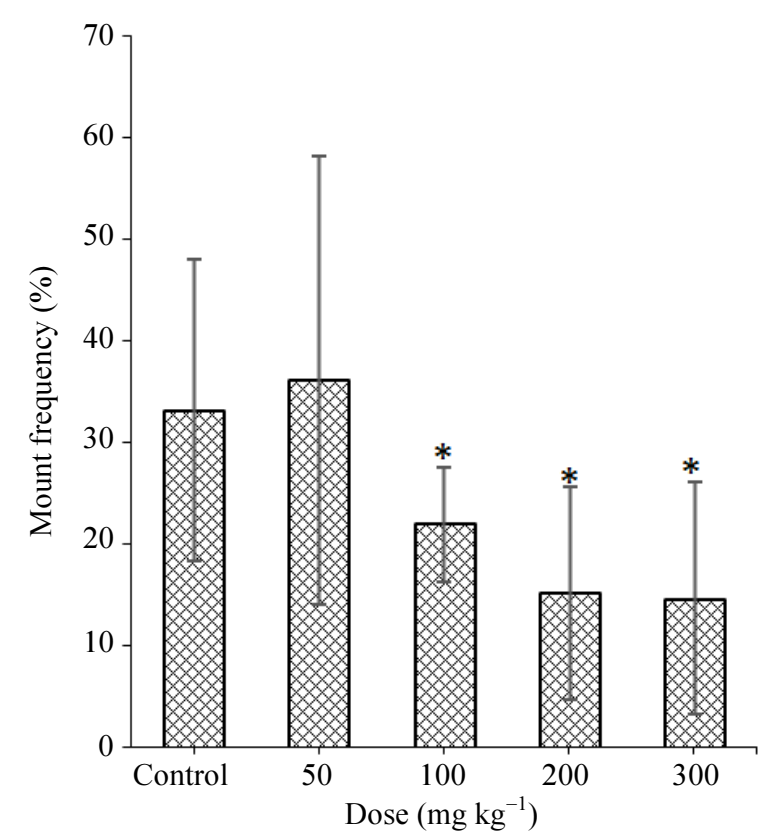

(a)

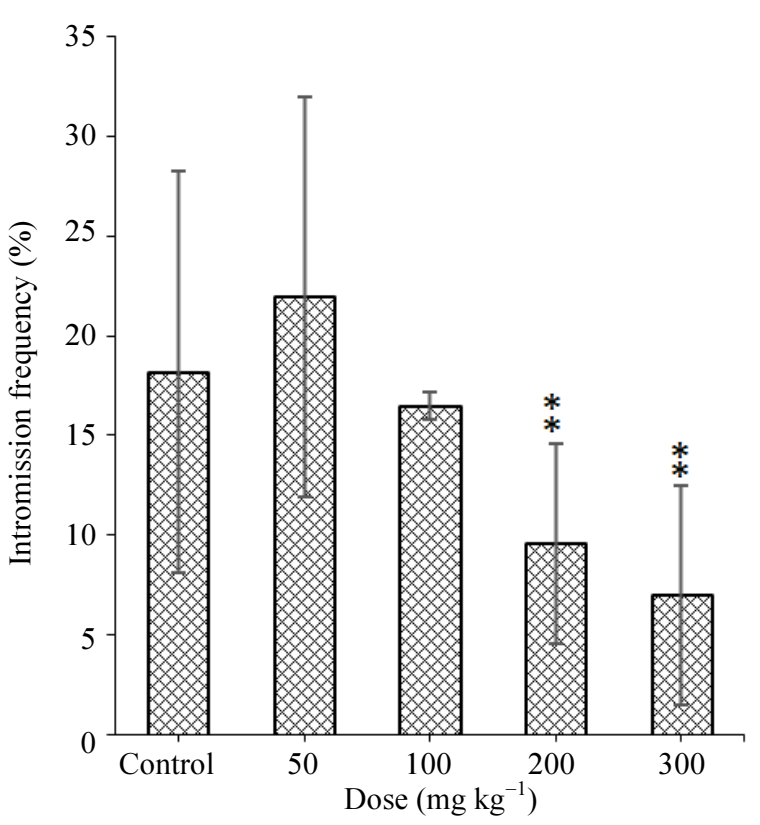

(b)

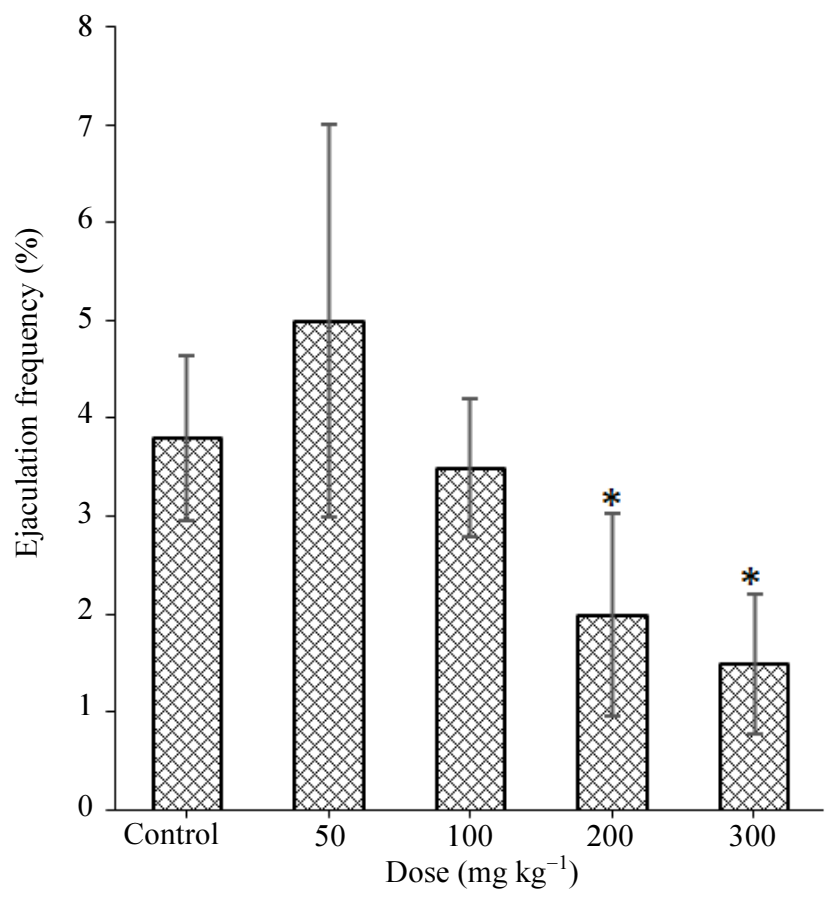

(c)

Fig. 1: Effects of ethanol $G$ kola seed extract on sexual behaviors: (a) Mount frequency (b) Intromission frequency and (c) Ejaculation frequency in Wistar rats; Values expressed as mean $\pm \mathrm{SD}, \mathrm{n}=6$ animals per group; ${ }^{*} \mathrm{p}<0.05,{ }^{*} \mathrm{p}<0.01$

Mount Frequency $(\mathrm{MF})$ was reduced $(\mathrm{p}<0.05)$ in rats that received 100-300 $\mathrm{mg} \mathrm{kg}^{-1}$ extract compared to control; but MF in $50 \mathrm{mg} \mathrm{kg}^{-1}$ extract treated rats was normal (Fig. 1a). Similarly, intromission frequency (number of intromissions) in all extract administered rats was reduced, but only values in 200 and $300 \mathrm{mg} \mathrm{kg}^{-1}$ treated rats were significant $(p<0.0023)$ when compared to control (Fig. 1b). Additionally, ejaculation frequency (number of ejaculations) in extract administered rats was reduced $(\mathrm{p}=$ $0.0344)$. The values were also significant $(p=0.0346)$ in 200 and $300 \mathrm{mg} \mathrm{kg}^{-1}$ treated rats, but not in 50 and $100 \mathrm{mg}$ $\mathrm{kg}^{-1}$ treated rats when compared with control (Fig. 1c). 


\section{Effect of Extract on Sperm Parameters}

There was no significant difference $(p=0.4015)$ in sperm motility between extract administered rats and control (Fig. 2a). Comparison of the different test groups with control did not also show any significant difference (Fig. 2a). Sperm count, viability and morphology in rats that received $50 \mathrm{mg} \mathrm{kg}^{-1}$ extract were not altered (Fig.

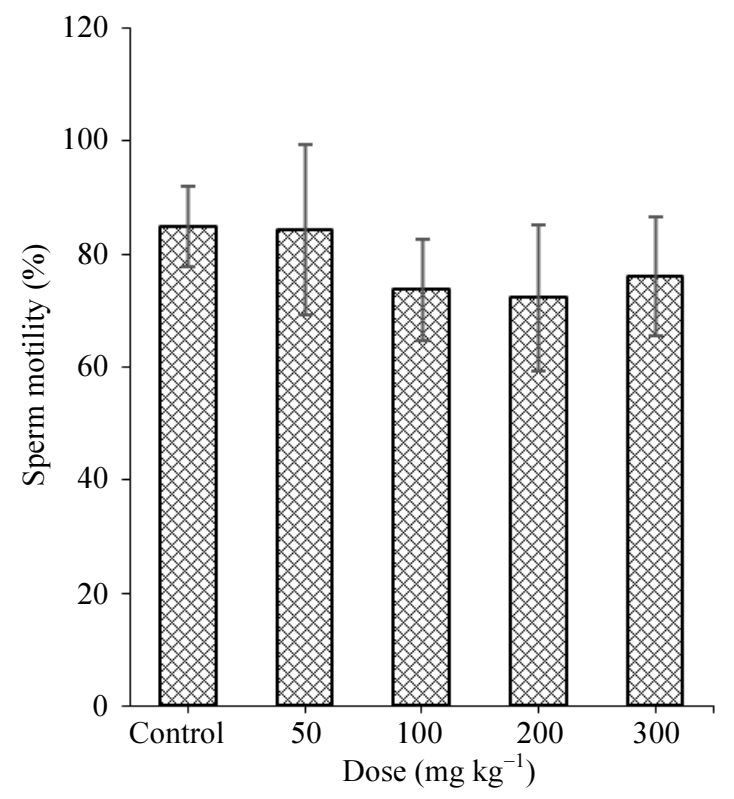

(a)

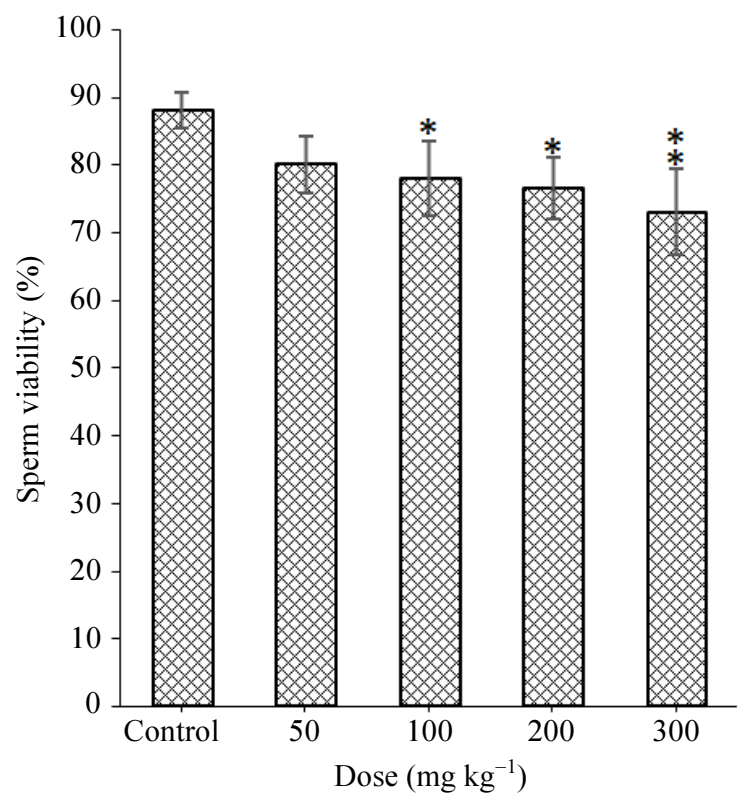

(c) 2b-2d), but sperm count and viability in $100-300 \mathrm{mg} \mathrm{kg}^{-1}$ extract treated rats were decreased $(\mathrm{p}<0.0001, \mathrm{p}=$ 0.0011 ) in a dose-dependent fashion when compared with control (Fig. $2 b$ and 2c). Percentages of sperms with structural abnormalities (abnormal sperm morphology) in $100-300 \mathrm{mg} \mathrm{kg}^{-1}$ extract treated rats were elevated $(\mathrm{p}<0.001)$ compared to control (Fig. 2d).

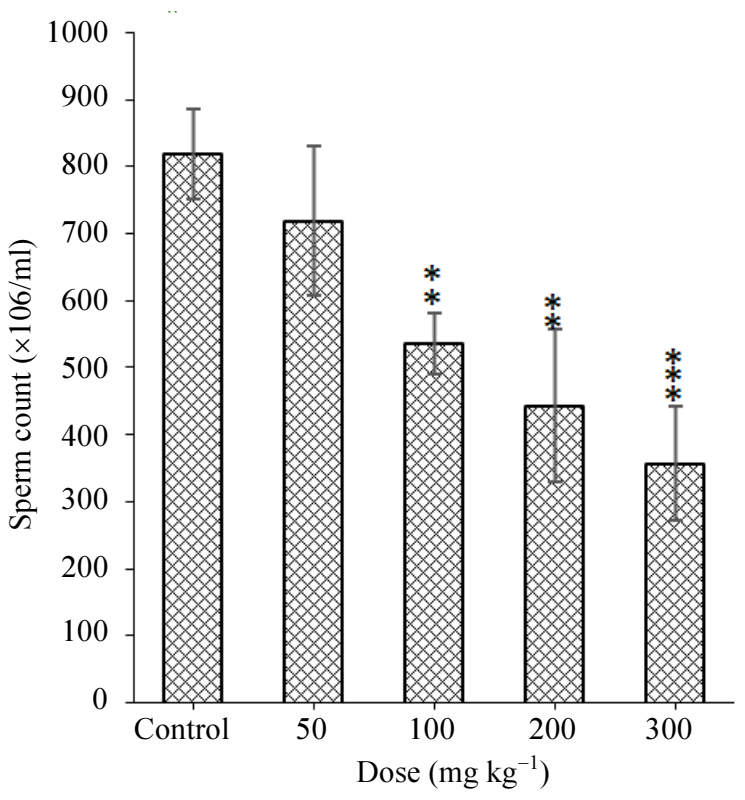

(b)

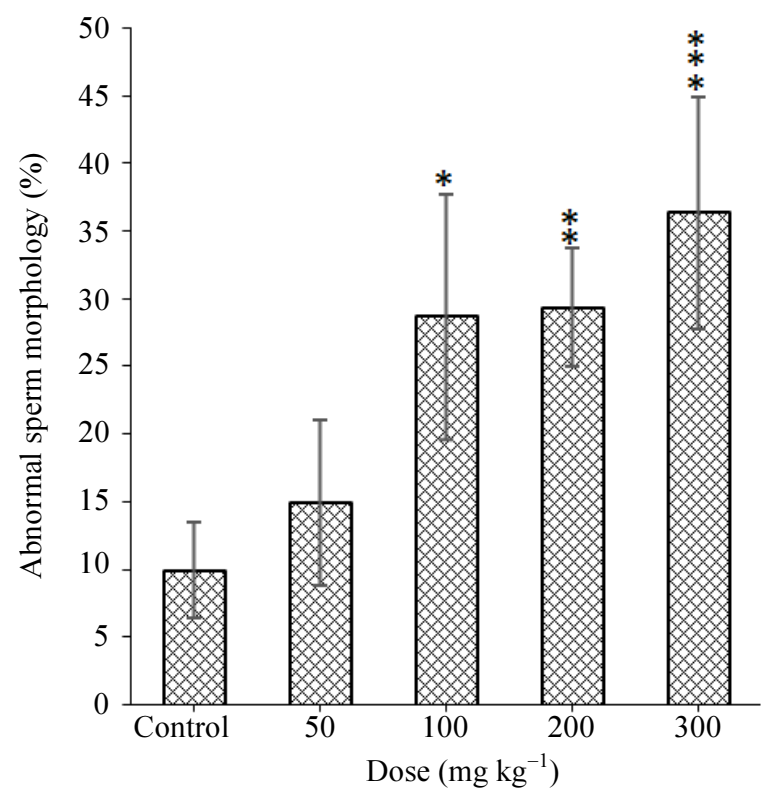

(d)

Fig. 2: Effects of ethanol seed extract of G kola on sperm parameters: (a) Sperm motility (b) Sperm count (c) Sperm viability and (d) Abnormal sperm morphology (percentage of morphologically abnormal sperm cells) in Wistar rats; Values expressed as mean $\pm \mathrm{SD}, \mathrm{n}=6$ animals per group; ${ }^{*} \mathrm{p}<0.05,{ }^{*} \mathrm{p}<0.01,{ }^{* * *} \mathrm{p}<0.0001$ 


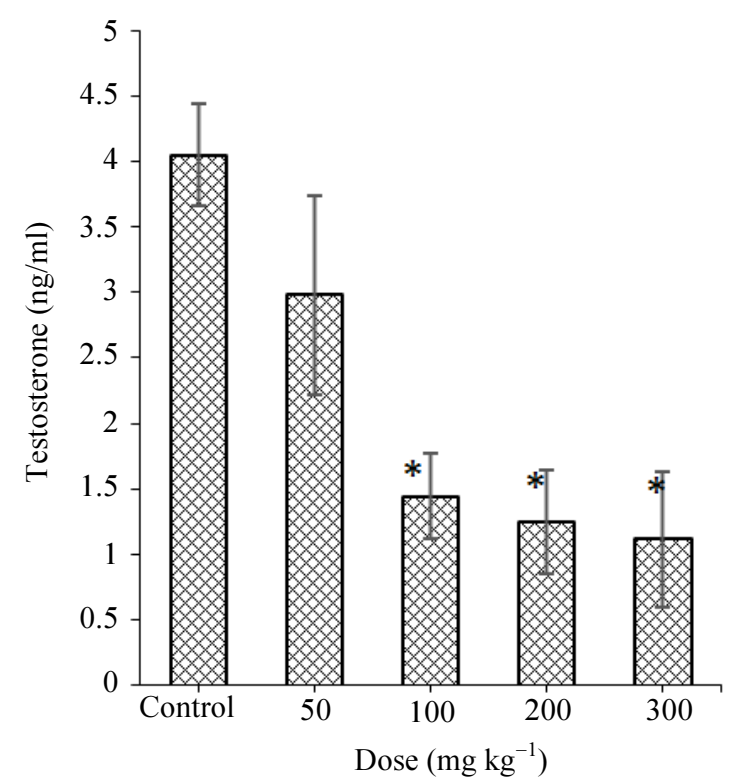

(a)

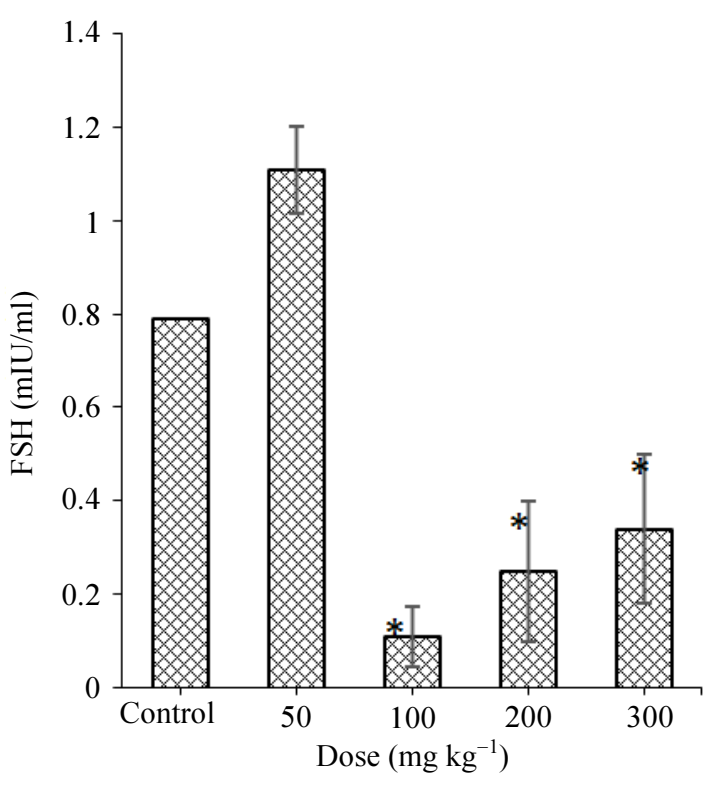

(b)

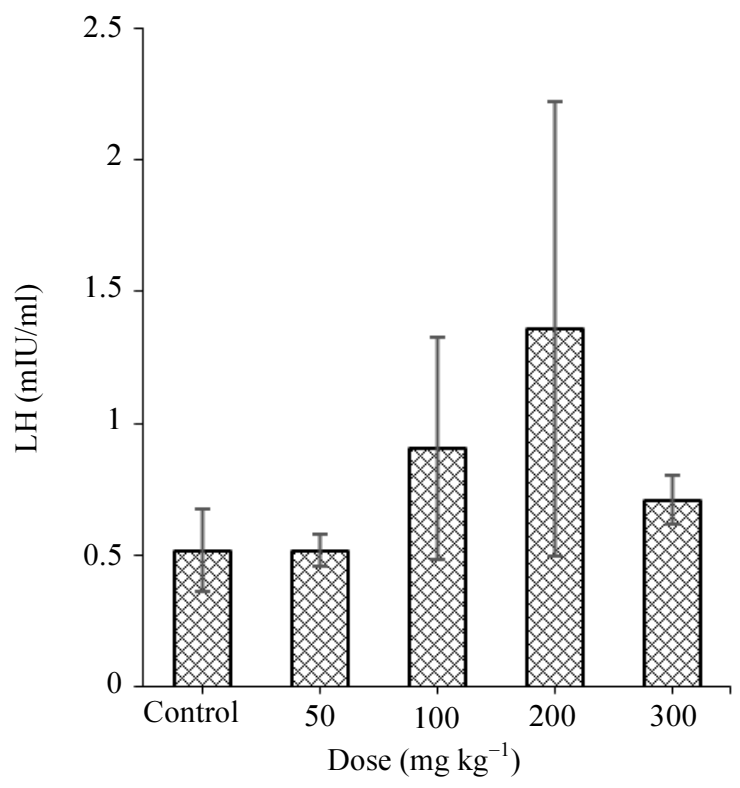

(c)

Fig. 3: Effects of ethanol seed extract of G kola on serum levels of (a) Testosterone (b) Follicle stimulating hormone (FSH) and (c) Luteinizing hormone $(\mathrm{LH})$ in Wistar rats; Values expressed as mean $\pm \mathrm{SD}, \mathrm{n}=6$ animals per group; ${ }^{*} \mathrm{p}<0.0001$

Table 3:Pregnancy rate and liter size of female rats mated with vehicle (control) and Garcina kola seed extract treated male Wistar rats

\begin{tabular}{|c|c|c|c|}
\hline Dose $(\mathrm{mg} / \mathrm{kg})$ & $\begin{array}{l}\text { Number of pregnancies } \\
\text { that occurred }\end{array}$ & $\begin{array}{l}\text { Percentage of } \\
\text { pregnancies that occurred }\end{array}$ & Litter size $($ Mean \pm SD) \\
\hline Control & $6(6)$ & 100 & $8.67 \pm 1.80$ \\
\hline 50 & $6(6)$ & 100 & $8.33 \pm 2.44$ \\
\hline 100 & $2(6)$ & 33.33 & $2.50 \pm 0.71 * \hbar$ \\
\hline 200 & $0(6)$ & 0 & 0 \\
\hline 300 & $0(6)$ & 0 & 0 \\
\hline
\end{tabular}

$\mathrm{n}=6$ per group; $*$ Significant at $\mathrm{p}=0.0072$, compared to control $(t$-test $) ;{ }^{\dagger}$ Significant at $\mathrm{p}=0.0165$, compared to $50 \mathrm{mg} \mathrm{kg}^{-1}$ extract $(t$-test $)$ 


\section{Effect of Extract on Reproductive Hormones}

Serum concentrations of testosterone, FSH and LH were not affected by the lowest dose of the extract compared to control (Fig. 3a-3c). But in rats that were administered higher doses of the extract (100-300 mg $\left.\mathrm{kg}^{-1}\right)$, serum testosterone level was decreased $(\mathrm{p}<0.0001)$, FSH level was decreased $(\mathrm{p}<0.0001)$; whereas LH was not altered (Fig. 3a-3c).

\section{Effect of Extract on Fertility}

Pregnancy occurred in all female rats $(100 \%)$ that were mated with control or $50 \mathrm{mg} \mathrm{kg}^{-1}$ extract treated male rats (Table 3). Pregnancy was observed in only two rats $(33.33 \%)$ in $100 \mathrm{mg} \mathrm{kg}^{-1}$ extract administered rats, whereas no pregnancy $(0 \%)$ occurred in 200 or $300 \mathrm{mg}$ $\mathrm{kg}^{-1}$ extract administered rats (Table 3 ). In addition, average number of pups (litter size) that was delivered by pregnant animals in control $(8.67 \pm 1.16)$ and $50 \mathrm{mg} \mathrm{kg}^{-1}$ administered rats $(8.33 \pm 1.53)$ were comparable and not significantly different from each other, but their values were both higher $(p=0.0072)$ compared to the litter size $(2.50 \pm 0.50)$ in $100 \mathrm{mg} \mathrm{kg}^{-1}$ extract treated rats (Table 3$)$.

\section{Discussion}

Garcina kola is a popular medicinal plant that is consumed by many for diverse purposes. The seed of the plant is claimed locally in some areas to enhance fertility and sexual activities (Iwu, 1989). However, there is no established scientific evidence of this claim as results from previous studies are simply contrasting. The present study reports the effect of $G$. kola ethanol seed extract treatment on sexual behavior, sperm characteristics, reproductive hormones and fertilizing capacity in male rats.

Precoital behaviors with mounting, intromission and ejaculation activities are useful factors that are used to assess male sexual dysfunction in animal models (Cimanga et al., 2016). From our results, the lowest dose of the extract $\left(50 \mathrm{mg} \mathrm{kg} \mathrm{kg}^{-1}\right)$ produced high precoital behaviors of chasing, nosing, sniffing and genital grooming in the animals comparable to the levels that were exhibited by control rats. Similarly, the extract at this dose did not alter animals' Mount Frequency (MF), Intromission Frequency (IF) or Ejaculation Frequency (EF) of the rats during the observation period of $20 \mathrm{~min}$. Surprisingly, the higher doses of the extract $\left(100-300 \mathrm{mg} \mathrm{kg}^{-1}\right)$ produced reduction of these sexual activities in the rats. This was characterized by reduced expression or absence of precoital behaviors, as well as low MF, IF and EF which demonstrate low sexual desire. Previously, Ralebona et al. (2012) had reported that ethanol extract (200-400 mg kg-1) given for 28 days enhanced sexual activity and increased testosterone in Wistar rats. Sewani-Rusike et al. (2016) demonstrated that ethanol extract at $100-400 \mathrm{mg} \mathrm{kg}^{-1}$ when administered for 28-50 days possesses aphrodisiac activity in Wistar rats, but effect was more at lower doses. On the other hand, Yakubu and Quadri (2012) showed that G. kola (25-100 $\left.\mathrm{mg} \mathrm{kg}^{-1}\right)$, administered over a period of $200 \mathrm{~h}$ does not enhance sexual activity. From the result obtained in the present study, low dose levels of $G$. kola seed may have no effect, whereas high dose levels may slow sexual desire in rats.

The results equally indicated that daily extract treatment for 30 days reduced sperm count and viability. Our study equally showed that $G$. kola treatment increased percentage of abnormally shaped sperm cells (abnormal sperm morphology). This finding is in agreement with some earlier studies (Akpantah et al., 2003; Chilaka et al., 2009; Abua et al., 2013; Mesembe et al., 2013), but differ from a few others who reported increase in sperm count after 6 weeks of extract treatment in Wistar rats (Adesanya et al., 2007; Sewani-Rusike et al., 2016). The extract had been reported to cause sperm motility reduction (Adesanya et al., 2007; Chilaka et al., 2009; Mesembe et al., 2013), but there was no change in motility in the present study which is consistent with the result of Sewani-Rusike et al. (2016). The negative spermatogenic effects observed in this study suggest that the extract is likely to alter spermatogenesis (sperm production), which occurs in the seminiferous tubules of the testis. Testosterone, the androgen hormone, plays an essential role in spermatogenesis and its reduction as observed in this study could contribute to the reduced sperm count obtained. Further, the non-alteration in serum LH concentration that was seen indicates that feedback control response of anterior pituitary to the testosterone reduction signal in the testis was absent (Neill and Herbison, 2006). This suggests that the extract might affect the testis, partly via interference of the endocrine regulatory function. This observation is in agreement with an earlier study which demonstrated that G. kola treatment caused gross cellular depletion and desquamation of cells of the testis, hypothalamus and pituitary with resultant alteration in the histology of the hypothalamic-pituitary-gonadal axis (Obi and Nwoha, 2014). In addition, our result on testosterone was similar with many earlier findings (Braide et al., 2003; Chilaka et al., 2009; Abua et al., 2013), but was not consistent with the studies of Ralebona et al. (2012) and Sewani-Rusike et al. (2016) who reported the opposite. Although, variations in extraction vehicle and duration of treatment in some of the studies cited above could influence the nature of the results obtained, the wide range of contrasting results suggest that studies on the subject remains in-exhaustive at the moment.

Finally, our results showed that the lowest dose of the extract $\left(50 \mathrm{mg} \mathrm{kg}^{-1}\right)$ did not alter fertility, but higher doses reduced fertility capacity of male rats. Animals that received 200 and $300 \mathrm{mg} \mathrm{kg}^{-1}$ extract 
failed to cause pregnancy, whereas at $100 \mathrm{mg} \mathrm{kg}^{-1}$, extract reduced pregnancy rate as well as number of pups delivered. This suggests that high concentrations of the extract possesses antifertility potential, which correlates positively with the adverse spermatic effects produced by the extract. Phytochemicals that were found in the plant extract includes, flavonoids, alkaloids, saponins, tannins, terpenoids and steroids. The composition of these compounds may be partly responsible for the results that were obtained.

\section{Conclusion}

The results of the study demonstrate that low concentrations of $G$. kola seed extract neither alter sexual behavior nor exhibit adverse effect on the testis. But high concentrations of the extract may reduce sexual behavior, alter sperm characteristics, and reduce testosterone and fertility potential in male rats following prolong administration.

\section{Acknowledgement}

Authors thank laboratory staff of the Department of Experimental Pharmacology and Toxicology, University of Port Harcourt for providing technical assistance.

\section{Authors' Contributions}

Aprioku conceived and designed the study. Okeke, Emakpor and Nwachukwu managed the literature searches. All authors contributed in conduction of the experiments and collection of the data. Aprioku, Okubuike and Igbo handled the analysis of the data. Aprioku wrote the first draft of the manuscript and all authors approved the final manuscript.

\section{Funding}

No external funding.

\section{Conflict of Interests}

The authors declare that there are no conflicts of interest with respect to the research, authorship and/or publication of this article.

\section{References}

Abua, A.H., P.O. Amutab, E. Bubab and T.R. Inusab, 2013. Evaluation of antispermatogenic effect of Garcinia kola seed extract in Albino rats. Asian Pacific J. Reproduct., 2: 15-18.

Adegboye, M.F., D.A. Akinpelu and A.I. Okoh, 2008. The bioactive and phytochemical properties of Garcinia kola (heckle) seed extract on some pathogens. African J. Biotechnol., 7: 3934-3938.
Adesanya, O.A., K.A. Oluyemi, D.A. Olusori, I.O. Omotuyi and C.U. Okwuonu et al., 2007. Micromorphometric and stereological effects of ethanolic extracts of Garcinia cambogia seeds on the testes and epididymides of adult Wistar rats. Internet J. Alternative Med., 5: 1-9.

Adesina, S.K., Z.O. Gbile and O.A. Odukoya, 1995. Survey of indigenous plants of West Africa with special emphasis on medicinal plants and issues associated with management. The United Nations Programme on Natural Resources in Africa.

Akpantah, A.O., A.A. Oremosu, M.O. Ajala, C.C. Noronha and A.O. Okanlawon, 2003. The effect of crude extract of Garcinia kola seed on the histology and hormonal milieu of male Sprague-Dawley rats' reproductive organs. Nigerian J. Health Biomed. Sci., 2: 40-46.

Atsukwei, D., S.O. Odeh, U.G. Egesie and J.E. Toryila, 2015. Effect of ethanolic extract of Garcinia kola seed on some reproductive parameters of male Wister rats. IOSR J. Pharmacy, 5: 04-10.

Baker, D.J., 2007. Semen analysis. Clin. Laboratory Sci., 20: 172-187. PMID: 17691673

Barata, A.M., F. Rocha, V. Lopes and A.M. Carvalho, 2016. Conservation and sustainable uses of medicinal and aromatic plants genetic resources on the worldwide for human welfare. Industrial Crops Products, 88: 8-11. DOI: $10.1016 /$ j.indcrop.2016.02.035

Braide, B., C.A. Agube, G.E. Essien and F.V. Udoh, 2003. Effect of Garcinia kola seed alkaloid extract on levels of gonadal hormones and pituitary gonadotrophins in rat serum. Nigerian J. Physiol. Sci., 18: 59-64.

CCAC, 2009. The care and use of farm animals $n$ research, Teaching and Testing. Canadian Council on Animal Care, Ottawa, Canada.

Chilaka, K.C., I.N. Nweke and L.A. lroegbulam, 2009. Evaluation of the anti-fertility effect of Garcinia kola seeds on male-Guineapigs. Tropical J. Med. Res. DOI: 10.4314/tjmr.v13i1.65420

Chinnoch, P., 1996. Reproductive health. African Health, 18: 3-19.

Cimanga, K.R., L.M. Ntondele, M.C. Kikweta, M.B. Mbamu and M.P. Nsompi et al., 2016. Assessment of aphrodisiac activity of diazostimul ${ }^{\circledR}$, a phytomedicine based aqueous extract of the root bark of Heinsia crinata (Afzel.) G. Taylor (Rubiaceae) and its acute toxicity. World J. Pharmacy Pharmaceutical Sci., 5: 271-292.

Emokpae, M.A., P.O. Uadia and A.Z. Mohammed, 2005. Hormonal evaluations and endometrial biopsy in infertile women in Kano, Northern Nigeria: A comparative study. Annals African Med., 4: 99-103.

Ibiblio, J.O., 1983. Some medicinal plants of Nigeria. Ibadan Publishers Nig. Ltd., Nigeria. 
Iwu, M.M., 1989. Food for Medicine. In: Dietary Plants and Masticatories as Sources of Biologically Active Substances, Iwu, M.M. (Ed.), University of Ife Press, Nigeria.

Kutzler, M.A., 2007. Estrus induction and synchronization in canids and felids. Theriogenology, 68: 354-374. DOI: 10.1016/j.theriogenology.2007.04.014

Lopez, H.H., G. Wurzel and B. Ragen, 2007. The effect of acute bupropion on sexual motivation and behavior in the female rat. Pharmacol. Biochem. Behav., 87: 368-379.

DOI: $10.1016 /$ j.pbb.2007.05.014

Mascarenhas, M.N., S.R. Flaxman, T. Boerma, S. Vanderpoel and G.A. Stevens, 2012. National, regional and global trends in infertility prevalence since 1990: A systematic analysis of 277 health surveys. PLoS Med., 9: e1001356-e1001356. DOI: 10.1371/journal.pmed.1001356

Mesembe, O.E., O.R Asuquo, V.A. Fischer, G.U. Udoaffah and C.C. Mfem et al., 2013. Influence of long-term ingestion of Garcinia kola seed diet on sperm count, sperm motility and fertility in Wistar rats. J. Health Med. Nurs., 1: 20-22.

Neill, J.D. and A.E. Herbison, 2006. Physiology of the Gonadotropin-Releasing Hormone Neuronal Network. In: Knobil and Neill's Physiology of Reproduction, Neill, J.D. (Ed.), Elsevier, Amsterdam.

Ngueyem, A.G., G. Brusotti, Caccialanza and P. VitaFinzi, 2009. The genus Bridelia: A phytochemical and ethnopharmacological Review. J. Ethnopharmacol., 124: 339-349. PMID: 19477259

Obi, A.U. and P.U. Nwoha, 2014. Effects of kolaviron, the major constituent of Garcinia kola, on the histology of the hypothalamus, pituitary and testes using adult male Wistar rats as a model organism. Forensic Med. Anatomy Res., 2: 80-87.

Ochei, O. and A. Kolhatker, 2002. Medical Laboratory Science, Theory and Practice. 5th Edn., Tata McGraw-Hill Publishing Company Ltd., New Delhi.
Ofor, M.O., C.A. Ngobili and M.I. Nwufo, 2004. Ethnobotanical uses and trade characteristics of Garcinia kola in Imo State, Nigeria. Int. J. Agric. Rural Dev., 5: 140-144.

Okonofua, F., U. Menakaya, S.O. Onemu, L.O. OmoAghoja and S. Bergstrom, 2005. A case-control study of risk factors for male infertility in Nigeria. Asian J. Androl., 7: 351-361.

DOI: $10.1111 / \mathrm{j} .1745-7262.2005 .00046 . x$

Okoye, T.C., P.F. Uzor, C.A. Onyeto and E.K. Okereke, 2014. Safe African medicinal plants for clinical studies. Toxicol. Survey African Med. Plants, 18: 2-15. DOI: 10.1016/B978-0-12-800018-2.00018-2

Ralebona, N., C.R. Sewani-Rusike and B.N. NkehChungag, 2012. Effects of ethanolic extract of Garcinia kola on sexual behaviour and sperm parameters in male Wistar rats. African J. Pharmacy Pharmacol., 6: 1077-1082.

DOI: $10.5897 / A J P P 11.652$

Sewani-Rusike, C.R., N. Ralebona and B.N. NkehChungag, 2016. Dose- and time-dependent effects of Garcinia kola seed extract on sexual behaviour and reproductive parameters in male Wistar rats. Andrologia, 48: 300-307. DOI: 10.1111/and.12447

Sofowora, A. 1993. Medicinal Plants and Traditional Medicine in Africa. 2nd Edn., Spectrum Books, Ibadan, Nigeria.

Trease, G.E. and M.C. Evans, 2009. Text book of Pharmacognosy. 15th Edn., Bailliere Tindal, London.

Yakubu, M.T. and A.L. Quadri, 2012. Garcinia kola seeds: Is the aqueous extract a true aphrodisiac in male Wistar rats? African J. Traditional Complement Alternative Med., 9: 530-535.

DOI: 10.4314 /ajtcam.v9i4.9 